УДК 338.439:636.22/.28(477)

(C) 2012

Шиян Н. І., кандидат економічних наук

Харківський національний аграрний університеті імені В. В. Докучаєва

\title{
ОКУПНІСТЬ ВИТРАТ НА ВИРОБНИЦТВО МОЛОКА В СІЛЬСЬКОГОСПОДАРСЬКИХ ПІДПРИЕМСТВАХ: СТАН ТА ЧИННИКИ ФОРМУВАННЯ
}

\section{Рецензент - доктор економічних наук, професор М. О. Бєсєдін}

\begin{abstract}
У роботі висвітлено актуальність проблеми підвищеення рівня окупності витрат у процесі виробництва молока та можливі иляхи ї̈ вирішення. 3 використанням методу групувань визначено ступінь впливу цุіни реалізації та собівартості одиниці продукиї на рівень окупності витрат у сільськогосподарських підприємствах України, які у 2010 р. виробляли і реалізовували молоко. Підтверджено існування тісного зворотнього зв'язку між показниками «продуктивність корів» та «собівартість одинииі продукиї», виявлено в 2010 р. існування залежності між рівнем изін і продуктивності корів, які змінюються в одному напрямку - зростають.
\end{abstract}

Ключові слова: окупність витрат, иіна, собівартість, продуктивність, інтенсифікація, велика рогата худоба (ВРХ).

Постановка проблеми. Однією з проблем, що активно обговорюються в аграрній економічній літературі, є забезпечення стабільного розвитку галузі тваринництва, передусім скотарства. Актуальність іiі розгляду обумовлена низкою причин, найважливішою $з$ яких $є$ існування негативної тенденції до зниження чисельності поголів'я ВРХ, у тому числі корів, зменшення обсягів виробництва продукції галузі, а відтак, і зниження ступеня забезпечення потрібного населенню рівня споживання продукції галузі вітчизняного виробництва. Так, починаючи з 2006 р., виробництво молока зменшується. Якщо у 2005 р. обсяги його виробництва дорівнювали 13714,4 тис. т, то у 2010 р. вони становили 11248,5 тис. тонн. I це за умов, коли, відповідно до низки законодавчих документів ставилося завдання довести обсяги виробництва молока у 2015 р. до 20 млн тонн [8].

Однією з причин становища, яке склалося у розвитку даної галузі, є недостатній рівень прибутковості в процесі виробництва продукції, а в окремих випадках і глибока збитковість, особливо в реалізації ВРХ на м'ясо. Наслідком цього стала відсутність одного з важливих мотивів, що спонукає до розвитку галузі в нинішніх умовах розвитку економіки, - недостатній рівень окупності витрат у процесі виробництва молока.
Аналіз останніх досліджень і публікацій, у яких започатковано розв'язання проблеми. Наукові праці провідних вчених-економістів присвячені різним аспектам вирішення означеної проблеми: стосовно аграрної сфери України взагалі, й щодо розвитку скотарства. Так, до розгляду факторів, що мають безпосередній вплив на прибутковість аграрних підприємств, в одній із своїх публікацій звернулися Л. М. Мельник i П. М. Макаренко [2]. В окремих роботах висвітлено результати досліджень щодо ефективності розвитку скотарства в сільськогосподарських підприємствах України, зокрема у Львівській області [1]. Увага науковців приділясться і розгляду механізмів регулювання цін із боку держави [3]. Важливе значення мало створення нормативно-правової бази, відповідно до якої здійснюється регулювання розвитку галузі за сучасних умов [4-7], що й забезпечило позитивні результати у 2010 році, коли рівень рентабельності молока дорівнював $17,9 \%$, рівень окупності витрат, відповідно, 1,179. Однак за такої умови не вдалося здолати збитковість ВРХ, реалізованої на м'ясо.

Незважаючи на значну кількість публікацій, які відображають результати грунтовних досліджень проблем скотарства, а відтак, і конструктивні пропозиції щодо їх вирішення, на нашу думку, в них недостатньо представлені можливості здійснення таких заходів, які б дали змогу одночасно вирішити двоєдине завдання: підвищувати ціни реалізації й знизити собівартість одиниці продукції, що і виступає підгрунтям для суттєвого підвищення окупності витрат.

Метою дослідження було визначення впливу відмінностей у цінах реалізації і собівартості одиниці реалізованої продукції на рівень окупності витрат при виробництві молока в сільськогосподарських підприємствах України, які в 2010 р. виробляли і реалізовували молоко.

Відповідно до поставленої мети вирішувалися наступні завдання: з'ясувати, якою мірою окупність витрат на продукцію скотарства формуєть- 
ся в межах одного року під впливом відмінностей у цінах реалізації й собівартості реалізованої продукції, а також визначити причини, під впливом яких формуються зазначені відмінності.

Результати дослідження. Загальновідомо, що особливе значення для формування прибуткового виробництва має ціновий механізм. Тому на першому етапі наших досліджень ми звернулися до аналізу показників динаміки цін на головні види продукції. Загальна тенденція у їх зміні свідчить про невпинне зростання їх величини, однак за наявності певних відхилень (табл. 1).

Як видно 3 даних таблиці, протягом аналізованого періоду відбувалося значне підвищення цін реалізації по всіх продуктах. Однак у найбільшій мірі ціни зросли на молоко і молочні продукти - в 15,3 разу, а найменше - на зернові культури - в 6,7 разу. Якщо ж співставити середні ціни реалізації у 2010 р., у порівнянні 32009 р., то зміна відбулася таким чином: по зернових культурах ціна зросла на 40,3 \%, по молоку і молочних продуктах - на 55,6 \%, а по великій рогатій худобі (у живій масі) зростання було незначним - на $8,1 \%$.

Оскільки по представлених видах продукції рентабельність виробництва у 2010 р. зросла, то це свідчить про те, що ціна реалізації в цьому році зросла більш високими темпами у порівнянні зі зростанням собівартості одиниці продукції. В інші роки це співвідношення формувалося по-різному, але загальна тенденція полягала в підвищенні не лише цін реалізації, а й собівартості одиниці продукції. У статистичних довідниках відповідні дані, на жаль, виявити не вдалося, що ускладнює проведення аналізу.

Проте і за таких умов можна 3'ясувати, що icнують суттєві відмінності у величині показників як цін реалізації, так і собівартості одиниці продукції, до того ж навіть на рівні регіонів. Так, при середній ціні реалізації молока і молочних продуктів у 2010 р. 2938,7 грн/т в Одеській області вона дорівнювала 2487,0 грн/т, збільшившись за рік на 46,9 \%, у м. Києві - 3417,4 грн/т при зростанні за рік на 14,7 \%. Найбільше ціна зросла у Сумській області - на 64,4 \%, але все одно вона була нижчою від середньої по Україні, дорівнюючи 2894,3 грн/т. Слід також зауважити, що зростання ціни реалізації молока по підприємствах м. Києва пов'язане $з$ реалізацією частини молока не переробним підприємствам, по яких вона практично співпадала із середніми цінами по Україні, а з реалізацією по інших каналах, за якими ціни зростали до 6400 грн/т.

\section{1. Динаміка цін і темпів їх зміни по основних видах сільськогосподарської продукції} в сільськогосподарських підприємствах Украӥни протягом 1996-2010 рр.

\begin{tabular}{|c|c|c|c|c|c|c|}
\hline \multirow{2}{*}{ Рік } & \multicolumn{2}{|c|}{ Зернові культури } & \multicolumn{2}{c|}{ ВРХ (у живій масі) } & \multicolumn{2}{c|}{$\begin{array}{c}\text { Молоко та молочні } \\
\text { продукти }\end{array}$} \\
\cline { 2 - 7 } & $\begin{array}{c}\text { ціна реаліза- } \\
\text { ції, грн/т }\end{array}$ & $\begin{array}{c}\text { до попередньо- } \\
\text { го року, \% }\end{array}$ & $\begin{array}{c}\text { ціна реалізації, } \\
\text { грн/т }\end{array}$ & $\begin{array}{c}\text { до попередньо- } \\
\text { го року, \% }\end{array}$ & $\begin{array}{c}\text { ціна реалі- } \\
\text { зації, грн/т }\end{array}$ & $\begin{array}{c}\text { до поперднь- } \\
\text { го року, \% }\end{array}$ \\
\hline 1996 & 168,4 & 100,0 & 832,1 & 100,0 & 191,5 & 100,0 \\
\hline 1997 & 176,1 & 104,6 & 883,5 & 106,2 & 239,5 & 125,1 \\
\hline 1998 & 154,2 & 87,6 & 1239,6 & 140,3 & 284,1 & 118,6 \\
\hline 1999 & 200,4 & 130,0 & 1498,3 & 120,9 & 360,4 & 126,9 \\
\hline 2000 & 443,8 & 221,5 & 2071,4 & 138,3 & 536,4 & 148,8 \\
\hline 2001 & 381,3 & 85,9 & 3567,7 & 172,2 & 603,7 & 112,5 \\
\hline 2002 & 312,5 & 82,0 & 2918,8 & 81,8 & 541,0 & 89,6 \\
\hline 2003 & 535,1 & 171,2 & 2736,5 & 93,8 & 696,9 & 128,8 \\
\hline 2004 & 453,1 & 84,7 & 4359,0 & 159,3 & 835,3 & 119,9 \\
\hline 2005 & 417,8 & 92,2 & 5885,0 & 135,0 & 1126,9 & 134,9 \\
\hline 2006 & 515,2 & 123,3 & 5293,6 & 90,0 & 1070,2 & 95,0 \\
\hline 2007 & 833,5 & 161,8 & 5854,9 & 110,6 & 1660,6 & 155,2 \\
\hline 2008 & 778,6 & 93,4 & 9414,8 & 160,8 & 2065,1 & 124,4 \\
\hline 2009 & 799,0 & 102,6 & 8711,2 & 92,5 & 1888,8 & 91,5 \\
\hline 2010 & 1120,9 & 140,3 & 9415,0 & 108,1 & 2938,7 & 155,6 \\
\hline 2010 p. & 6,7 разу & - & 11,3 paзy & - & 15,3 разу & - \\
\hline до 1996 p. & & & & & \\
\hline
\end{tabular}


Зрозуміло, що найбільші коливання і ціни реалізації, й собівартості одиниці продукції відбувалися на рівні підприємств. Тому наступним етапом досліджень став аналіз результатів групування сільськогосподарських підприємств за рівнем їх рентабельності, здійснений Державним комітетом статистики України. Було використано дані групування за 2009 і 2010 роки. Оскільки рентабельність виробництва у ці роки, як уже зазначалося, суттєво змінилася, то, відповідно, змінився й підхід до аналізу показника, за яким здійснювалося формування груп підприємств. Проте міжгруповий інтервал був однаковий 0,049. Однак якщо у 2009 р. кількісно переважали групи зі збитковим виробництвом, то у 2010 р. ситуація змінилася. Крім цього зауважимо, що в статистичному збірнику наведені дані про рівень собівартості та рентабельності (збитковості) по сукупності і групах підприємств. Відсутні дані про ціни реалізації були розраховані. Спочатку здійснили перехід від показника рентабельності до показника окупності шляхом додавання до першого $100 \%$, а далі перемножили собівартість 1 ц реалізованої продукції на показник окупності витрат, визначивши ціну реалізації. Отримані результати представлені в таблиці 2.

Як бачимо, при переході від однієї групи до іншої у міру зростання рівня окупності витрат передусім відбувається підвищення собівартості 1 ц реалізованої продукції й одночасно - зростання ціни реалізації. Визначення коефіцієнта парної кореляції між двома показниками дало такі результати: у 2009 р. - мінус 0,9259 (показники останньої групи не бралися до уваги внаслідок їі нетиповості), у 2010 р. - мінус 0,6603.

Зрозуміло, що в нинішніх умовах розмір витрат в окремих суб'єктів господарювання не може виступати підставою для визначення ціни на продукцію цього підприємства, поскільки діють інші принципи ціноутворення. Тим більше це не може виступати підставою для підвищення цін реалізації на підприємствах із низькими показниками собівартості й, навпаки, підвищення їх для підприємств із високою собівартістю. Для визначення інших чинників ми розглянули залежності по підприємствах України, які у 2010 р. займалися виробництвом молока.

Дослідження здійснювалося 3 використанням методу групувань. Виробництвом і реалізацією молока у цьому році займалося 2311 підприємств. Дана сукупність за величиною окупності витрат була поділена на сім груп. Результати групування представлені в табл. 3. Передусім привертає увагу та обставина, що у 2010 р., як і в попередні роки, сформувалися досить значні відмінності у рівнях окупності витрат. Величина цього показника в групі 3 найвищим рівнем окупності витрат $(2,346)$ перевищувала показник групи з найнижчою окупністю $(0,401)$ в 5,9 разу. Коли звернулися до показників 2009 р., то знову з'ясувалося, що 17,3 \% підприємств досягли рівня прибутковості в розмірі $38,6 \%$, а в той же час існували групи підприємств із рівнем збитковості $75,6 \%$ і навіть $88,2 \%$ [8].

2. Собівартість і ціни реалізацї̈ в групах підприємств Украйни з різним рівнем рентабельності виробництва молока*

\begin{tabular}{|c|c|c|c|c|c|}
\hline \multicolumn{2}{|c|}{$2009 \mathrm{p}}$. & \multicolumn{3}{|c|}{$2010 \mathrm{p.}$} \\
\hline $\begin{array}{c}\text { Підприємства } \\
\text { з рівнем } \\
\text { окупності }\end{array}$ & $\begin{array}{c}\text { Ціна реалізації, } \\
\text { грн/ц }\end{array}$ & $\begin{array}{c}\text { Собівартість } \\
\text { реалізованої } \\
\text { продукції, грн/ц }\end{array}$ & $\begin{array}{c}\text { Підприємства } \\
\text { з рівнем } \\
\text { окупності }\end{array}$ & $\begin{array}{c}\text { Ціна реалізації, } \\
\text { грн/ц }\end{array}$ & $\begin{array}{c}\text { Собівартість } \\
\text { реалізованої } \\
\text { продукції, грн/ц }\end{array}$ \\
\hline до 0,149 & 158,12 & 1340,0 & - & - & - \\
\hline $0,150-0,299$ & 94,25 & 386,3 & до 0,299 & 165,58 & 629,59 \\
\hline $0,300-0,349$ & 108,60 & 335,2 & $0,300-0,349$ & 117,85 & 351,79 \\
\hline $0,350-0,499$ & 116,50 & 261,2 & $-0,350-0,499$ & 175,25 & 401,94 \\
\hline $0,500-0,649$ & 119,92 & 204,3 & $0,500-0,649$ & 163,83 & 276,74 \\
\hline $0,650-0,799$ & 133,70 & 179,7 & $0,650-0,799$ & 197,68 & 267,14 \\
\hline $0,800-0,899$ & 150,59 & 175,1 & $0,800-0,899$ & 207,35 & 241,10 \\
\hline $0,900-0,999$ & 148,27 & 156,4 & $0,900-0,999$ & 215,31 & 226,17 \\
\hline $1,00-1,050$ & 156,72 & 153,2 & $1,00-1,050$ & 231,53 & 226,55 \\
\hline $1,051-1,100$ & 162,69 & 151,2 & $1,051-1,100$ & 241,60 & 225,79 \\
\hline $1,101-1,150$ & 167,44 & 149,5 & $1,101-1,150$ & 237,54 & 211,71 \\
\hline $1,151-1,200$ & 164,69 & 140,4 & $1,151-1,200$ & 236,43 & 201,56 \\
\hline 1,201 і більше & 171,59 & 123,8 & 1,201 і більше & 254,47 & 171,13 \\
\hline у середньому & 155,75 & 153,6 & У середньому & 237,45 & 201,4 \\
\hline
\end{tabular}

* Примітка. Використано дані Державної служби статистики України і власні розрахунки 
Таким чином, є всі підстави стверджувати, що існує стійка тенденція щодо формування значної відмінності між рівнями окупності витрат у процесі виробництва молока в сільськогосподарських підприємствах України, у зв'язку з чим 3'ясування причин формування відмінностей у рівні окупності витрат набуває особливої актуальності.

Щодо характеру змін цін реалізації та собівартості 1 ц реалізованого молока в міру підвищення окупності витрат, то в обох випадках позначені тенденції мають протилежне спрямування: ціни реалізації зростають, а собівартість знижується. До того ж відмінність між показниками крайніх груп набагато більша саме за собівартістю: вона дорівнює, відповідно, 130,9 грн/ц і 490,5 грн/ц. Таким чином, у групі з найвищим рівнем собівартості на виробництво і реалізацію 1 ц продукції витрачається коштів у 3,7 разу більше у порівнянні з групою, що має мінімальну собівартість. Абсолютний розмір відмінності показників дорівнює 359,6 грн.

Значні відмінності спостерігаються також у цінах реалізації - від 196,8 до 307,0 грн/ц, - тобто в 1,6 разу. Абсолютний розмах міжгрупової відмінності ціни реалізації, таким чином, дорівнює 110 гривень.
Особливої уваги заслуговує те, що для групи 3 найвищою окупністю витрат характерна найбільш сприятлива обставина: ціни реалізації найвищі, а собівартість 1 ц найнижча. Слід зазначити, що аналогічне становище було характерне й для попереднього року, причому собівартість виробництва 1 ц реалізованої продукції дорівнювала 123,8 грн, а ціна реалізації - 171,59 гривні.

Ціна реалізації і собівартість виробництва реалізованої продукції, безпосередньо впливаючи на формування окупності витрат, одночасно залежать від сукупної дії цілої низки чинників. У результаті попередніх досліджень, у тому числі й проведених нами, було встановлено, що особливе значення щодо цього мають концентрація виробництва і рівень продуктивності корів, який слід розглядати як інтегральну характеристику рівня інтенсивності.

Проведене дослідження засвідчило: в основі підвищення окупності витрат лежить підвищення продуктивності, яка (за одним винятком) зростала від однієї групи до іншої. До того ж зростання продуктивності впливало на окупність витрат, перш за все, через зниження собівартості. Коефіцієнт парної кореляції між цими показниками дорівнював 0,913 .

\section{3. Групування сільськогосподарських підприємств Украӥни за рівнем окупності витрат} у процесі виробництва молока у 2010 році

\begin{tabular}{|c|c|c|c|c|c|c|c|c|c|}
\hline \multirow[b]{2}{*}{ Показник } & \multicolumn{8}{|c|}{ Групи } & \multirow[b]{2}{*}{$\begin{array}{l}\text { У серед- } \\
\text { ньому }\end{array}$} \\
\hline & до 0,500 & $\begin{array}{c}0,501- \\
0,750\end{array}$ & $\begin{array}{c}0,751- \\
1,000\end{array}$ & $\begin{array}{c}1,001- \\
1,250\end{array}$ & $\begin{array}{c}1,251- \\
1,500\end{array}$ & $\begin{array}{c}1,501- \\
1,750\end{array}$ & $\begin{array}{l}1,751- \\
2,000\end{array}$ & $\begin{array}{c}\text { понад } \\
2,001\end{array}$ & \\
\hline Окупність & 0,401 & 0,660 & 0,904 & 1,105 & 1,363 & 1,605 & 1,843 & 2,346 & 1,178 \\
\hline Кількість господарств & 99 & 212 & 601 & 702 & 367 & 172 & 78 & 80 & 2311 \\
\hline $\begin{array}{c}\text { Поголів'я корів } \\
\text { із розрахунку на } \\
\text { підприємство, гол. }\end{array}$ & 65 & 137 & 194 & 260 & 291 & 306 & 258 & 204 & 230 \\
\hline $\begin{array}{c}\text { Із розрахунку } \\
\text { на підприємство: } \\
\text { - валове виробництво } \\
\text { молока, ц } \\
\end{array}$ & 1110 & 3756 & 6621 & 10609 & 13218 & 13182 & 11502 & 10376 & 9183 \\
\hline $\begin{array}{c}\text { - реалізовано молока, } \\
\text { ц }\end{array}$ & 795 & 3120 & 5739 & 9610 & 11997 & 11964 & 9755 & 9098 & 8191 \\
\hline Рівень товарності, \% & 71,6 & 83,1 & 86,7 & 90,6 & 90,8 & 90,8 & 84,5 & 87,7 & 89,2 \\
\hline $\begin{array}{c}\text { Середньорічний надій } \\
\text { від } 1 \text { корови, кг }\end{array}$ & 1708 & 2742 & 3413 & 4080 & 4542 & 4308 & 4458 & 5086 & 3993 \\
\hline $\begin{array}{l}\text { Величина витрат } \\
\text { на } 1 \text { корову, грн }\end{array}$ & 8679 & 7618 & 7658 & 8617 & 8411 & 7133 & 6400 & 6303 & 7984 \\
\hline $\begin{array}{c}\text { Повна собівартість } \\
1 \text { ц, грн }\end{array}$ & 490,5 & 319,5 & 274,0 & 242,8 & 206,8 & 178,5 & 158,0 & 130,9 & 229,0 \\
\hline $\begin{array}{c}\text { Ціна реалізації } 1 \text { ц, } \\
\text { грн }\end{array}$ & 196,8 & 210,9 & 247,6 & 268,3 & 281,9 & 286,5 & 291,2 & 307,0 & 269,81 \\
\hline
\end{tabular}


Тобто, саме рівень продуктивності корів безпосередньо впливає на формування собівартості одиниці продукції, зумовлюючи iї значення. Проте це стає можливим унаслідок того, що темпи зростання продуктивності виявилися помітно вищими, у порівнянні з темпами зростання витрат на корову, які виступають основою підвищення продуктивності. Продуктивність корів збільшилась із 1708 кг у першій групі до 5086 кг - у восьмій, або втричі, в той час як рівень витрат на 1 корову коливався.

Однак, якщо зворотна залежність між собівартістю і продуктивністю корів була очікуваною, то одночасне зростання продуктивності й ціни реалізації не можна прогнозувати з високою вірогідністю. Пояснюється цей факт тим, що, поперше, високому рівню продуктивності відповідає високий рівень технології й організації виробництва, що обумовлює отримання молока високої якості, i, як наслідок, - підвищення цін реалізації. По-друге, в цьому ж напрямі відбувається й зростання концентрації виробництва молока як шляхом збільшення поголів'я корів із розрахунку на підприємство, так і збільшення виробництва на основі підвищення продуктивності, бо ціни передусім суттєво зростали у тих групах підприємств, для яких характерним є суттєве збільшення обсягів виробництва у порівнянні із попередньою групою. Слід також зазначити, що в сьо-

\section{БІБЛІОГРАФІЯ}

1. Козіна Н. Ю. Ефективність розвитку скотарства у сільськогосподарських підприємствах Львівщини / Н. Ю. Козіна // Економіка АПК. - 2010. № 5. - C. 31-34.

2. Мельник М. Ю. Фактор и впливу на прибутковість аграрних підприємств / Л. Ю. Мельник, П. М. Макаренко, Л. Л. Мельник // Економіка АПК. - 2010. - № 5. - С. 79-86.

3. Місюк М. В. Про державне регулювання розвитку галузі скотарства / М. В. Місюк // Економіка АПК. - 2009. - № 4. - С. 112-116.

4. Про затвердження мінімально допустимого рівня цін на продукцію тваринництва на 2011 р.: погоджено проект Постанови КМУ рішенням № 997 від 12.10.2010 // [Електронний ресурс]. Режим доступу: http://www.dkrp.gov.ua.

5. Про затвердження Порядку використання ко- мій і восьмій групах, сформованих за рівнем окупності витрат, ціни реалізації молока зростали на тлі зменшення поголів'я корів із розрахунку на підприємство і навіть зменшення обсягів виробництва молока. Тобто, чинник концентрації впливає на зміну цін реалізації неоднозначно. Можливо, в цьому випадку діють ті самі чинники, які мають суттєве значення для зростання продуктивності корів.

Проведені дослідження, 3 нашого погляду, дають підстави зробити такі висновки:

1. По-перше, в складних умовах розвитку скотарства існують підприємства, що мають високий рівень окупності витрат у процесі виробництва продукції.

2. По-друге, на формування величини окупності витрат значний вплив справляе насамперед величина повної собівартості, що формується відповідно до загальної величини витрат і продуктивності тварин, і саме продуктивність тварин може розглядатися як фактор, що дає змогу зменшити собівартість одиниці продукції.

3. По-третє, темпи зростання цін є набагато меншими, ніж темпи зменшення повної собівартості одиниці продукції від групи до групи у процесі виробництва молока, що може свідчити про більш значну роль у формуванні величини окупності витрат саме останніх.

штів, передбачених у державному бюджеті для розвитку тваринництва: Постанова КМУ від 18.03.2009 p. № 282 (зі змінами та доповненнями) [Електронний ресурс]. // Режим доступу: http://search.ligazakon.ua.

6. Про затвердження розмірів бюджетної тваринницької дотації на 2011 рік: Постанова КМУ від 2.03.2011 p. № 182 // [Електронний ресурс]. Режим доступу: http://zakon.rada.gov.ua.

7. Про затвердження галузевої Програми розвитку молочного скотарства України до 2015 року: наказ Міністерства аграрної політики України № 886/128 від 10.12.2007.// [Електронний ресурс]. - Режим доступу: http://zakon.nau.ua.

8. Сільське господарство України 2009 р. / Держ. ком. стат. України. - К., 2010. - С. 60. 